\title{
Erratum to: Retrospective Open Access Articles
}

Published online: 3 October 2017

(C) The Author(s) 2017. This article is published with open access at Springerlink.com

\section{Erratum to: Agron Sustain Dev}

$$
\begin{aligned}
& \text { https://doi.org/10.1007/s13593-016-0359-9; } \\
& \text { https://doi.org/10.1007/s13593-016-0362-1; } \\
& \text { https://doi.org/10.1007/s13593-016-0393-7; } \\
& \text { https://doi.org/10.1007/s13593-017-0429-7 }
\end{aligned}
$$

Below listed articles:

"Exploring the role of smartphone technology for citizen science in agriculture" written by Katharina Dehnen-Schmutz, Gemma L. Foster, Luke Owen, Séverine Persello. Published online: 8 April 2016.

"Plant drought survival under climate change and strategies to improve perennial grasses. A review" written by Mark R. Norton, Dariusz P. Malinowski, Florence Volaire. Published online: 19 April 2016.

"Viruses carried to soil by irrigation can be aerosolized later during windy spells" written by Guillaume Girardin, Pierre Renault, Fabienne Bon, Line Capowiez, Joël Chadoeuf, Camille Krawczyk, Dominique Courault.
Published online: 12 October 2016.

"A new analytical framework of farming system and agriculture model diversities. A review" written by Olivier Therond, Michel Duru, Jean Roger-Estrade, Guy Richard. Published online: 6 June 2017.

were originally published electronically on the publisher's internet portal (currently SpringerLink) without open access.

With the society's decision to grant Open Choice the copyright of these articles changed to (C) The Author(s) and the articles are forthwith distributed under the terms of the Creative Commons Attribution 4.0 International License (http://creativecommons.org/licenses/by/4.0/), which permits use, duplication, adaptation, distribution and reproduction in any medium or format, as long as you give appropriate credit to the original author(s) and the source, provide a link to the Creative Commons license and indicate if changes were made. 